\title{
VESZÉLY- ÉS KATASZTRÓFA HELYZETEKBEN KELETKEZŐ HULLADÉKOK A KÖZÚTI KÖZLEKEDÉSBEN
}

\section{THE SAFETY TECHNOLOGY QUESTIONS OF WASTES ARISING IN THE COURSE OF CATASTROPHES IN THE CONTINENTAL TRAFFIC}

\author{
Kiss Leizer Géza Károly ${ }^{1}$, Berek Lajos ${ }^{2}$ \\ ${ }^{1}$ DPMV Zrt, 1183 Budapest, Széchenyi u 9,_kissleizer@t-online.hu \\ 2 Óbudai Egyetem, 1034 Budapest,Bécsi út 96/B, berek.lajos@bgk.uni-obuda.hu
}

\begin{abstract}
In my publication we present related to road transport shipment safety and waste management, taking into account safety issues that arise in accident and emergency situations, both domestic and international road transport regulations and waste disposal standards. The security solutions when examining the applicability of the main objective, identify gaps and facilitate appropriate expectations safe and efficient waste management.
\end{abstract}

Keywords: disasters, waste management, safety technology, cargo security, road transport, dangerous goods.

\section{Összefoglalás}

Publikációnkban bemutatjuk a közúti közlekedéshez kapcsolódó szállítmánybiztonságot, valamint a baleseti és katasztrófa helyzetekben felmerülő hulladékkezelési biztonságtechnikai kérdéseket a hazai és nemzetközi közúti közlekedési jogszabályok és hulladékkezelési előírások figyelembe vételével. A biztonságtechnikai megoldások alkalmazhatóságának vizsgálatakor legfőbb célkitüzésünk a hiányosságok feltárása és az elvárásoknak megfelelő biztonságos és hatékony hulladékkezelés segitése.

Kulcsszavak: katasztrófa, hulladékkezelés, biztonságtechnika, szállitmánybiztonság, közúti közlekedés, veszélyes áruk.

\section{Security of road transports}

The cargo could be a tool or material, transported by another device on a designated course from somewhere to anywhere in good order. Transportation may be accomplished on public roads, railways, waterways or in the air. Transportation is probably as old as humanity, but the level and importance of this activity has never been so determinate as today.
The most decisive way of forwarding is the road transport. Air conveyance is fast but expensive. Waterage and railway transport is too bound, depending on the riverbed or the quality of the railroad. Road transport is the most flexible solution, because the track of the cargo could be changed, supervised or optimized rapidly. [1]

The cargo could be grouped diversely. Considering the type of the cargo, the transported material or device could be broad, universal, hazardous or high value. 
The most common hazardous materials are the explosive-, extremely flammable-, toxic-, radioactive- and the infectious materials. The cargo must be secured, because the cargo itself could be endangered, or the cargo may pose a threat to the environment.

Security of the cargo (protection, defence) is a whole bulk of provisions, regulations and applied defence resources, which aims to deliver the cargo in time without damages, as planned. In light of this, protection and defence is the key to keep the cargo safe.

Guarding is a permanent counteraction responding to a presumed threat on the cargo. The guard so an insurance one attaching to a hypothetical, supposed activity, the protection it began though, a related averting task ensued with an event concerned. [3]

\section{Factors affecting technical secu- rity}

In order to permanently reduct wastes into the economical and social turnovers, it is necessary to reveal factors affecting engineering safety, to determine the elements of engineering safety in waste management, furthermore, the employability of these solutions. Engineering safety is a totality of technical and technological methods and procedures, which aims to secure the existence or the functioning of somebody or something. [3] During waste management this goal could be achieved by the appliance and utilization of engineering sciences. Doing this, every single element could be an influential factor, which holds the shaping, installation, maintenance or the creation of conditions of the engineering safety. From all of these, the most important element is the human factor. This could be manifested during vehicular catastrophes and accidents coming from malpractice or negligence, causing serious damages. [4]
We belive this is important to highlight and emphasize the role of hydrocarbons polluting the soil and aquatic life. These materials are mostly emerging in the wake of disasters and they often not burn out. We also have to mention other types of special industrial or delivered liquids. By this time, polluted area must be cleaned from these liquids and materials, which have been transformed into dangerous waste. [5]

\section{RFID identification of wastes coming from accidents and dis- asters}

Special events would take place due to the technical failures of the tank-cars or tank-containers. In light of this, exact location of the means of transportation must be traceable permanently, furthermore, all details of the cargo must be known. Due to the inappropriate embarkation and disembarkation and improper handling of doors and windows, a vehicle in neglected technical condition may damage even easier. In case of waste management, our personal behavior and the rules of traffic must be extended in order to manage an accident or catastrophe, to reduce the effects of hazardous materials and to hold polluting effects. These steps and know-how would be similar to the well known first aid exam, obligatory for all drivers. One of the possible solution to treat a damaged tanker is the appliance of the Vetter-pillows. These pillows are easy to deploy even by laymen. [6]

Today's most modern technical solutions and proceedings should be explored, in order to precisely identify hazardous waste, when these materials contact the environment during disasters and accidents. [2] Radio Frequency Identification (RFID) provides reading of the information carrier chip of the vehicle from safe distance by radio waves during disasters and accidents. This method also works at great speed of the vehicle. 
According to our recommendation, RFID is a more effective method of identification than conventional UN numbers visible on vehicles transporting hazardous materials. Based on the aforementioned operational specifications, the RFID systems would provide safer identification using radio frequency from approximately 150 meters. This solution could be effective at great range of speeds and places out of the way.

During catastrophes and accidents the vehicle often suffers so severe damage that UN numbers and other information of the cargo become unreadable. The information

carrier unit is also vulnerable, in this case, reading is also impossible. A rapidly employed drone would be capable to read a properly installed chip, in order to rapidly identify dangerous goods. Following this, obtained information must be transmitted to the units participating in the recovery. Possessing the necessary information, these units could prepare the appropriate tools of decontamination, protective clothing, etc. Shaping of the strategy of neutralization is also possible before taking actions at the location of the disaster.

The significance of this combined method is extraordinary, if the location of the disaster or accident is out of the way or impossible to approach. In case of poisoning, contamination or explosion the RFID system could help to save those who involved in the rescue process. The recommended procedure may significantly decrease pollution of hazardous wastes, because effluent, non-burning hazardous materials become hazardous waste by touching the ground. The affected area of the road and the environment also become contaminated, because of time factor and the fast spreading of the pollution. We would like to highlight that groundwater could be also polluted when hydrocarbons diffuse into the soil. 1 liter of liquid hydrocarbon could vitiate 1 million liter of water.

\section{With drones against waste}

The drone is a small, propeller driven unmanned aerial vehicle, available for multiple useful tasks. Drones' applicability could be demonstrated by their employment in American metropolises, where illegal waste dumping was reduced, following the appearance of these aerial vehicles. This problem is also cardinal in Hungary, where illegal waste dumping is a common phenomenon along the roads, inhabited regions, parking places and green areas.

\subsection{Options of application of drones}

- Identification of dangerous goods;

- Temperature-monitoring of tankers;

- Monitoring of illegal waste dumping;

- Inspection of technical status of roads and road signs;

- Protection against illegal access and expropriation of hazardous cargo;

- Supervision of displacement, downfall, leakage, dusting of the cargo,

- Supervision of damages, doors and windows of road vehicles;

- Measurement of radiation level of radioactive waste during conveyance;

- Monitoring of accident- and catastrophe locations, immediate forwarding of the listed information.

The complexity of these opportunities is very large. In light of this, we list only the most interesting ones, in connection with road traffic.

\subsection{Other areas of application for drones}

Aerial reconnaissance for civilian and military purposes, motion picture recording, photography, environmental meterage, parcel delivery, monitoring of agricultural areas (animals, plant production), application of thermal sensors, infrared camera, monitoring of waterways, GPS beacon, bluetooth- or wifi- beacon, motion sensor, face recognition, biometric scanner, target 
tracking, vehicle tracking, military purposes with firearms, accident- and catastrophe observation, surveillance, booster light and many other possibilities.

\subsection{Rules of application of drones}

All unmanned aerial vehicles - whatever their intended purpose - falls within the scope of the Law XCVII 1995. and CLXX 2015. on air transport. There is no integrated regulatory background referring to the unmanned aerial vehicles, i. e. drones. Comprehensive regularization of this aeronautical specialty - until the concerning law goes live - belongs to the Supervisory Department of the Aviation Authority (National Transport Authority).

Renewal of the legal regulation has to be done as soon as possible, to make all aspects unequivocal, because these anomalies may cause serious problems during everyday practice, furthermore, economical-social-environmental damages and may also hurt our feelings about waste security.

\section{Findings}

Based on our proposed solution, i. e. Radio Frequency Identification by drones would make transport vehicles' identification much more easier during road accidents and catastrophes, thereby decreasing possibility of waste generation. Mini-drones may approach locations of accidents and catastrophes very fast in difficult circumstances, too.

High security RFID reading, identification of dangerous goods, fast forwarding of information would be an inestimable help for the people taking part in actions of recovery.

Another important aspect is the lifesaving, the transmission of information for the environmental and other emergency units, in order to start decontamination and restoration of the area.

\section{References}

[1] Berek Lajos-Solymosi János: Veszélyes anyagok szállitmányának biztonsága, Bolyai Szemle 2015. 2. szám pp. 46-62 http://uninke.hu/uploads/media_items/bolyai-szemle2015-02.original.pdf (2016. 01. 25)

[2] Berek Tamás: Vagyonvédelmi koncepció kialakitásának sajátosságai veszélyes anyagok vizsgálatát biztositó létesitmények esetében, Hadmérnök VI. 4. szám 2011. http://hadmernok.hu/2011_4_berek.pdf (2016.01.25.)

[3] Dr. Berek Lajos: Biztonságtechnika, Nemzeti Közszolgálati Egyetem Bp. 2014. 49 p. http://real.mtak.hu/19709/1/biztonsagtechnik a.original.pdf (2016. 01.25.)

[4] Kiss Leizer Géza Károly: River and sea traffic safety issues regarding waste generated during disasters, Óbuda University eBulletin, ISSN 2062-2872 Volume 5 Issue Number $12015 . \quad$ http://uni-obuda.hu/ebulletin/issue6.htm (2016. 01. 25.)

[5] Kiss Leizer Géza Károly-Dr. Pokorádi László: Hulladékkezelési kérdések a légi közlekedésben, Repüléstudományi Közlemények XXVII. Évfolyam 2. szám pp. 17-25 http://www.repulestudomany.hu/folyoirat/20 15_2/2015-2-02-0190-Kiss_Leizer_G_KPok̄oradi_L.pdf (2016. 01. 25.)

[6] Kiss Leizer Géza Károly-Dr. Maros Dóra: Veszély és katasztrófa helyzetekben keletkezö hulladékok kezelése a vasúti közlekedésben, Közlekedéstudományi Szemle LXV. Évfolyam 3. szám pp. 58-65 